\title{
Solitary Juvenile Colonic Polyp Presenting Anaemia in Patients with Neurofibromatosis Type 1: A Case Report
}

\author{
Nörofibromatozis Tip 1 Hastasında Anemi ile Seyreden İzole Kolon \\ Juvenil Polip: Olgu Sunumu
}

\author{
(1) Mustafa Taner Bostancı, (1) İbrahim Yılmaz, (1) Mehmet Saydam, (1) Ahmet Seki \\ Ankara Dışkapı Training and Research Hospital, Clinic of General Surgery, Ankara, Turkey
}

\section{|HIIIIII ABSTRACT}

Gastrointestinal lesions are seen in 10-25\% of NF1 patients, but generally they are underestimated by physicians because of their asymptomatic course. A thirtythree-year old male patient reffered to our hospital for anemia evaluation. NF1 physical findings; Lisch Nodules, Cafe u lait macules and neurofibromas were present. Colonoscopy reveled a 5x3 $2 \mathrm{~cm}$ sized hemorrhagicpolyp in proximal transvers colon and laparoscopic right hemicolectomy was performed. Histopathological diagnosis was juvenile polyp with low-grade dysplasia. Molecular genetic testing detected NF1 gene mutation. Upper and lower gastrointestinal endoscopy should be performed for all NFl patients to determine gastrointestinal involvement.

Keywords: Anemia, juvenile colonic polyp, neurofibromatosis type 1

\section{|IIIIIII| ÖZ}

NF1 hastalarının \%10-25’inde gastrointestinal tutulum saptansada, asemptomatik klinik seyirleri nedeniyle genellikle gözardı edilirler. Hastanemize anemi nedeni araştırılmak üzere 33 yaşında erkek hasta sevk edildi. Hastanın ilk muayenesinde; NF1 bulguları; Lisch nodülleri, Cafe u lait lekeleri ve nörofibromlar tespit edildi. Kolonoskopide; transvers kolon proksimalinde 5x3×2 cm boyutlarında hemorajik polip tespit edildi ve laparoskopik sağ hemikolektomi ameliyatı uygulandı. Histopatolojik olarak düşük displazili juvenil polip saptandı. NF1 gen mutasyonu moleküler gen testi ile saptandı. NF1 hastaların hepsinde üst ve alt gastrointestinal sistem endoskopisi gastrointestinal tutulumu değerlendirmek için yapılmalıdır.

Anahtar Kelimeler: Anemi, kolon juvenil polip, nörofibromatozis tip 1

\section{Introduction}

Neurofibromatosis type 1 (NF1) is an autosomal dominant inherited disease, and among the tumour suppressor genes, the NF1 gene has a role in the pathogenesis. ${ }^{1,2}$ Approximately, $50 \%$ of patients have a first-degree relative diagnosed with NF1 and others have sporadic mutations. ${ }^{3}$ NF1 occurs in 1 of 3000-4000 individuals worldwide, and its diagnosis is based on clinical features declared by the National Institutes of Health in 19884: 1) six or more café au lait macules ( $>0.5 \mathrm{~cm}$ for children, $>1.5 \mathrm{~cm}$ for adults), 2) two or more neurofibromas of any type or one plexiform neurofibroma,
3) axillary or inguinal freckling, 4) optic glioma, 5) two or more Lisch nodules (iris hamartomas), 6) osteodysplasia (pseudoarthrosis, sphenoid dysplasia), and 7) one firstdegree relative diagnosed with NF1. The presence of two or more of the aforementioned clinical findings is adequate for NF1 diagnosis. ${ }^{4}$ Molecular genetic testing of NF1 is rarely essential, but single gene testing and chromosomal microarray analysis can be performed for pathogenic variants of NF1.

Gastrointestinal lesions are seen in $10 \%-25 \%$ of NF1 patients, but generally, they are underestimated by physicians because 
of their asymptomatic course. Gastrointestinal stromal tumours (GIST) are the most common gastrointestinal lesions of NF1 patients. ${ }^{5}$

Herein, we present a case of NF1 with solitary juvenile colonic polyp to draw attention on NF1 gastrointestinal lesions.

\section{Case Report}

A 33-year-old male patient referred to a primary care physician for fatigue, pallor, and dizziness. He was diagnosed with anaemia (haemoglobin $7.2 \mathrm{~g} / \mathrm{dL}$ ) and was transferred to our hospital for further evaluation.

The patient did not have a family history of NF1. Physical examination revealed mild pectus excavatum and numerous café au lait macules $0.5-2 \mathrm{~cm}$ in size and located on the thorax (Figure 1). Numerous submucosal lesions were found, which were diagnosed as neurofibromas histopathologically, on the back and upper extremities; the largest was $2 \mathrm{~cm}$ in size (Figure 1).

Esophagogastroduodenoscopy findings were unremarkable, but colonoscopy showed an ulcerated 5-cm polyp in the ascending colon, and it was a hamartomatous polyp on the colonoscopic biopsy. Molecular genetic testing detected NF1 gene mutation. Iris hamartomas (Lisch nodule) were detected in both eyes (Figure 2). Results of bone radiography and abdominal computed tomography were unremarkable. Cranial magnetic resonance imaging showed an 8.5-mm nodular mass located in the midbrain tectum (glioma?) and

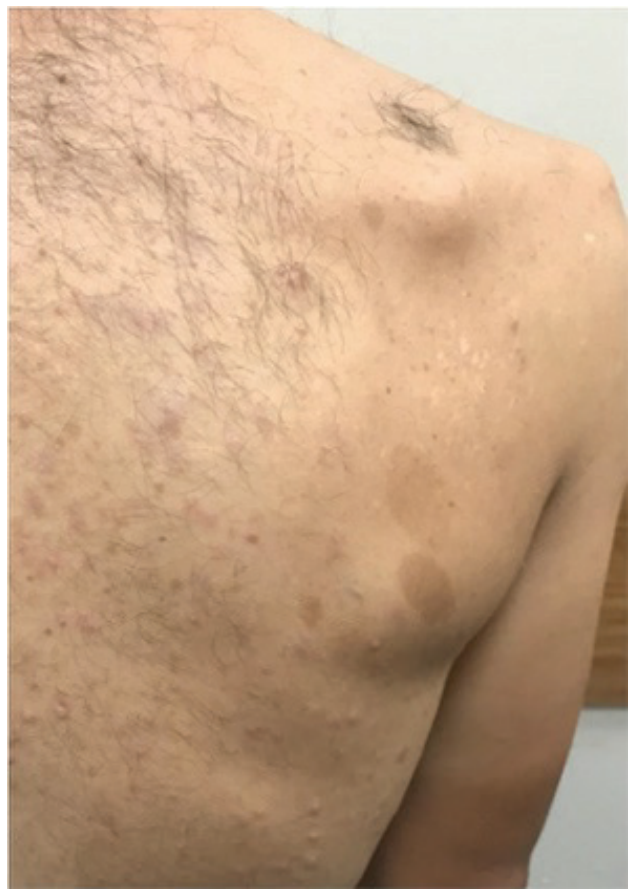

Figure 1. Cafu late macules and neurofibromas nodular lesions at the right centrum ovale (demyelinating plaque?).

Following three units of red blood cell as replacement, the patient underwent laparoscopic right hemicolectomy. Histopathological examination of the specimen showed a juvenile polyp $(5 \times 3 \times 2 \mathrm{~cm}$ in size $)$ with haemorrhagic surface in the proximal transvers colon and low-grade dysplasia and interlacing bundles of spindle cells extending into the lamina propria with comma-shaped nuclei, which is a specific finding of NF1 (Figure 3).

The patient was discharged on postoperative day 7 without any complication, and 3-month follow-up continued smoothly.

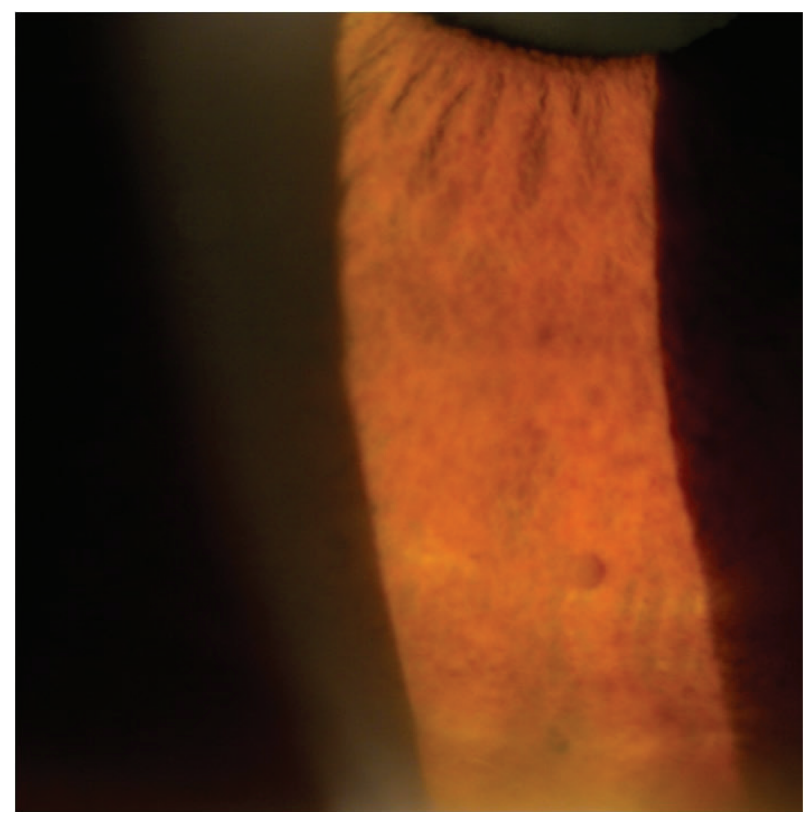

Figure 2. Lisch nodules

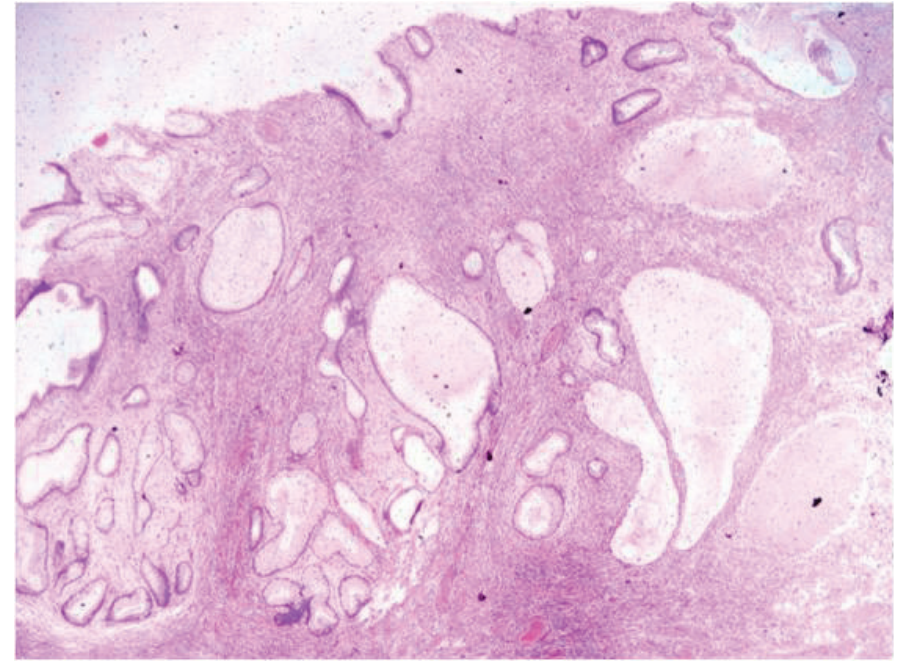

Figure 3. Enlarged irregular crypt structures in inflammatory and edemataous stroma 


\section{Discussion}

NF is one of the phacomatous diseases or neurocutaneous syndromes. NF 2 affects the central nervous system, while NF1 involves the cardiovascular, gastrointestinal, or skeletal system. ${ }^{5}$ Gastrointestinal NF1 neoplasms vary from benign and intermediate to rare aggressive malignant neoplasms. ${ }^{6}$ $\mathrm{NF} 1$ is frequently located at the upper gastrointestinal system, and colon involvement is rare. Gastrointestinal clinical findings occur sooner than cutaneous findings because of their asymptomatic nature. ${ }^{7}$ In the presented case, cutaneous lesions were more remarkable than gastrointestinal findings.

The level of mucosal involvement and localisation of the lesions determine the gastrointestinal symptoms, which present mostly as bleeding. ${ }^{8}$ In the present case, the patient was referred to our hospital for examination of anaemia, which was due to a haemorrhagic colonic polyp of NF1. Rarely, gastrointestinal lesions can cause volvulus or intussusception, resulting in mechanical bowel obstruction. ${ }^{9}$

GIST, neurogenic neoplasms (neurofibroma or ganglioneuroma), and neuroendocrine tumours are the three main forms of NF1 gastrointestinal neoplasms. ${ }^{7,10}$ Agaime et al. ${ }^{10}$ have described inflammatory polyps (non-adenomatous, juvenile-like polyps) which were not listed as NF1-related gastrointestinal lesions. These lesions are characterised by multiple mucosal protrusions, vasculopathic changes, hypervascularity, intense inflammatory infiltration, and histopathological fibroblastic proliferations which differed from NF1 histopathologic findings and classified as inflammatory polyps. ${ }^{10}$ Juvenile polyps should be considered in the differential diagnosis of NFl inflammatory polyps. NF1 juvenile polyps are rare clinicopathological conditions, and cases of coexistence of inflammatory and juvenile polyps in NF1 were reported. ${ }^{10,11}$ In the present case, the patient presented with occult gastrointestinal bleeding due to ascending colonic juvenile polyp with NF1. The absence of reactive inflammatory changes and neural structures histopathologically prompted diagnosis of juvenile polyp.

Juvenile polyps are hamartomatous polyps and contribute to a small portion of colorectal polyps. While the malignancy potential of solitary juvenile polyp is low, juvenile polyposis syndromes are at risk for colorectal malignancies. ${ }^{12}$ Although co-occurrence of NF1 and hamartomatous polyposis syndromes is described in the literature, solitary juvenile polyp co-occurrence has not been well described yet.

The overlapping findings and co-occurrence of hamartomatous and neurocutaneous syndromes can be result from the interaction of cellular signal transduction pathways at the molecular level. Therefore, genetic and molecular studies showing this interaction are needed to determine and monitor at-risk groups.

Screening, follow-up, and management of these lesions are still undetermined because of their rarity. We established that colonoscopic polypectomy and annual colonoscopy should be sufficient for management and follow-up. During follow-up, if malignant transformation occurs, colon resection should be performed according to oncological principles.

\section{Conclusion}

NF1 colonic involvement is a very rare clinical condition whose clinical findings will later present as gastrointestinal bleeding or mechanical bowel obstruction. Upper and lower gastrointestinal endoscopy are necessary for all NF1 patients to determine gastrointestinal involvement.

\section{Ethics}

Informed Consent: Written informed consent was obtained from the patient.

Peer-review: Internally and externally peer reviewed.

\section{Authorship Contributions}

Surgical and Medical Practices: M.T.B., A.S., Concept: M.T.B., A.S., Design: M.T.B., I.Y., Data Collection or Processing: M.T.B., M.S., Analysis or Interpretation: M.T.B., M.S., Literature Search: İ.Y., A.S., Writing: İ.Y.

Conflict of Interest: No conflict of interest was declared by the authors.

Financial Disclosure: The authors declared that this study received no financial support.

\section{References}

1. Hirbe AC, Gutmann DH. Neurofibromatosistype 1: a multidisciplinary approach to care. Lancet Neurol 2014;13:834-843.

2. Garrouche N, Ben Abdallah A, Arifa N, Hasni I, Ben Cheikh Y et al. Spectrum of gastrointestinal lesions of neurofibromatosis type 1: a pictorial review. InsightsImaging 2018;9:661-671.

3. Friedma JM, Riccardi VM. Neurofibromatosis: Phenotype, Natural History, and Pathogenesis, 3rd ed. Baltimore, MD: Johns Hopkins UniversityPress, 1999.

4. National Institutes of Health Consensus Divelopment Conference Statement. Neurofibromatosis. ArchNeurol (Chicago) 1988;45:575-578.

5. Agaimy A, Vassos N, Croner RS. Gastrointestinal manifestations of neurofibromatosis type 1 (Recklinghausen'sdisease):clinicopathological spectrum with pathogenetic considerations. Int J Clin Exp Pathol 2012;5:852-862.

6. Basile U, Cavallaro G, Polistena A, Giustini S, Orlando G, Cotesta D, et al. Gastrointestinal and retroperitoneal manifestations of type 1 neurofibromatosis. J Gastrointest Surg 2010;14:186-194.

7. Levy AD, Patel N, Dow N, Abbott RM, Miettinen M, Sobin LH. Abdominal neoplasms in patients with Neurofibromatosis type 1: radiologic-pathologic correlation. Radiographics 2005;25:455-480. 
8. Keese M, Riester T, Schwenke K, Dinter D, Back W, Palma P. Acute GI bleeding by multiple jejunal gastrointestinal autonomic nevre tumour associated with neurofibromatosis type I. Rev Esp Enferm Dig 2007;99:608-611.

9. Bakker JR, Haber MM, Garcia FU. Gastrointestinal neurofibromatosis: an unusual cause of gastric outlet obstruction. Am Surg 2005;71:100-105.

10. Agaimy A, Schaefer IM, Kotzina L, Knolle J, Baumann I, Störebel P, et al., "Juvenile-like (inflammatory/hyperplastic) mucosal polyps of the gastrointestinal tract in neurofibromatosis type 1," Histopathology 2014.2014;64:777-786.
11. Oktenli C, Gul D, Deveci MS, Saglam M, Upadhyaya M, Thompson P, Consoli C, Kocar IH, Pilarski R, Zhou XP, Eng C. Unusual features in a patient with neurofibromatosis type 1: multiple subcutaneous lipomas, a juvenile polyp in ascending colon, congenital intrahepatic portosystemic venous shunt, and horse shoe kidney. Am J Med Genet A 2004;127A:298-301.

12. Brosens LA, vanHattem A, Hylind LM, Iacobuzio-Donahue C, Romans KE, Axilbund J, et al. Risk of colorectalcancer in juvenilepolyposis. Gut 2007;56:965-967. 